\title{
Research on the Impact of New Reform Indicators on Current Human Resources Work of Electric Power Enterprises
}

\author{
Wang Han ${ }^{1, *}$ Tang Guangrui ${ }^{1}$ Liu Zuoming ${ }^{2}$ \\ ${ }^{1}$ State Grid Energy Research Institute Co.,Ltd., Beijing, 102209, China \\ ${ }^{2}$ State Grid Jilin Electric Power Co., Ltd. Electric Power Research Institute., Changchun, 130021, China \\ * Corresponding author's e-mail: wanghan@sgeri.sgcc.com.cn
}

\begin{abstract}
At present, the reform of state-owned assets and state-owned enterprises and the reform of the electric power system are continuously deepened, and new requirements are put forward for human resources management. Through an indepth analysis of the new reform situation, this article judges, summarizes and combs the impact of the reform of stateowned assets and state-owned enterprises and the reform of the power system on the construction of human resources teams. It provides a reference and reference for the state-owned power enterprises to deal with the impact of the reform situation on human resources work and improve the human resources team building system and mechanism.
\end{abstract}

Keywords: state-owned enterprise reform, power system reform, human resources management

\section{INTRODUCTION}

At present, the reform of state-owned assets and stateowned enterprises and the reform of the power system have advanced in depth, and the external environment faced by state-owned power companies has undergone great changes.

On the one hand, the reform of state-owned enterprises and state-owned enterprises has set new and higher requirements on the development goals, development speed, and development quality of stateowned enterprises. State-owned power companies need to constantly improve their internal environment to meet the new requirements for the reform of state-owned enterprises.[1] As an important foundation and strength of the company's reform and development, the workforce fundamentally affects the achievement of reform goals. Therefore, when faced with the major requirements for the reform of state-owned enterprises, state-owned enterprises should fundamentally adjust and improve the current workforce construction working mechanism, continuously improve the quality of employees, and stimulate the vitality of employees. The human resources management level and the overall quality of the workforce can meet the needs of enterprise reform and development, and lay a solid foundation for the early realization of the goals of state-owned enterprise reform.
On the other hand, the reform of the power system has brought tremendous pressure to state-owned power companies. As the market competition environment continues to intensify, state-owned power companies urgently need to increase profits by improving internal efficiency to cope with the increasingly fierce market competition. Effectively reducing labor costs and improving labor efficiency have become an important means and method for state-owned power companies to respond to power system reform.[2]

\section{THE INFLUENCE OF THE REFORM OF STATE-OWNED ASSETS AND STATE- OWNED ENTERPRISES ON THE COMPANY'S HUMAN RESOURCES TEAM}

Since the 18th National Congress of the Communist Party of China, the reform of state-owned assets and state-owned enterprises has proceeded steadily and has continued to advance in depth. Actively and steadily advancing the reform of mixed ownership, accelerating the transition from "managed enterprises" to "managed capital", and cultivating world-class enterprises with global competitiveness have become the focus of the reform of state-owned assets and state-owned enterprises. 


\subsection{The Overall Requirements for the Construction of Human Resources Teams in State-owned Enterprises have Changed}

As the reform of state-owned assets and state-owned enterprises entered the deep-water zone, the State-owned Assets Supervision and Administration Commission of the State Council has further increased its efforts in deregulation and management, accelerating the transition from "managed enterprises" to "managed capital". On the one hand, the State-owned Assets Supervision and Administration Commission reformed the state-owned capital authorization management system, clearly canceled, delegated, and authorized 43 functions, and introduced 27 systems in terms of system construction. On the other hand, we will promote the transformation of functions that focus on capital management, focusing on managing the distribution of state-owned capital, standardizing capital operations, improving capital returns, and maintaining capital security.

Through the formulation and implementation of the overall plan for the layout of the state-owned capital of central enterprises, the central, comprehensive and systematic allocation of state-owned capital in central enterprises will be strengthened, the state-owned capital's incremental guidance and stock adjustment will be strengthened, and the optimization of the state-owned capital layout will be promoted. This series of measures has a strong role in promoting the autonomy of stateowned enterprises and stimulating the vitality of stateowned enterprises. State-owned enterprises can break through the original administrative management system and establish a more flexible operation mechanism that adapts to market changes, effectively stimulating the innovative vitality of enterprises.[3]

However, most state-owned enterprises have been under stricter and standardized management by the SASAC for a long time in the past. They have always lacked initiative in clarifying the direction of enterprise development, making key major decisions, and expanding related business development. They generally work step by step under the guidance of the SASAC. Faced with decentralization of autonomy and management power, state-owned enterprises will definitely need a period of adaptation. The key core personnel, especially the operation and management personnel, must be able to quickly change their roles, from leading cadres to entrepreneurs, from national policy executors to company development decision makers. New requirements. Therefore, the state-owned power enterprises need to further clarify what capabilities and qualities the management personnel at all levels need to have under the new strategic development conditions based on the reform of state-owned enterprises The situation is compared, and it is clear which way and path to allocate the management team that meets the needs of strategic development for the company as soon as possible.

\subsection{External Efforts to Introduce High-end Talent are Increasing}

The Decision of the Central Committee of the Communist Party of China on Several Major Issues in Comprehensively Deepening Reform, which was passed at the Third Plenary Session of the Eighteenth Central Committee, proposed that the market should play a decisive role in the allocation of resources. Hao Peng, Secretary and Director of the Party Committee of the SASAC, emphasized at the Central Enterprise Talent Work Conference that we must adhere to the organic combination of party management talents and market allocation, and accelerate the improvement of the marketbased selection and employment mechanism.

State-owned power enterprises must closely follow the requirements of national policies, and strive to promote the reform of the "three systems", and promote the formation of a normalized mechanism in which employees can enter and exit, and cadres can go up and down. The influx of a large number of external personnel will have a major impact on the existing human resources team within the enterprise.

This means that the company's talent source will be more extensive, internal competition will be more encouraging, and the company's demand and strength for introducing talent from outside will increase, and regular adjustment of the human resources team through internal adjustment and external introduction will become Normal work. The criteria, quantity, channels, etc. of the introduction of external personnel are all issues that need to be considered. The introduction of external personnel must not only meet the company's current development needs and job requirements, but also the type of talent that the company urgently needs, and can play a good and effective supplement to the company's existing talent team.

Therefore, in the process of advancing the construction of market-oriented talent mechanism, stateowned power enterprises need to conduct an overall survey of the company's current talent team structure and quality. And on the basis of internal optimization and integration, combined with the new situation of stateowned and state-owned enterprise reforms and the company's strategic development needs, it is clear that the demand for external talents is introduced, so as to recruit and select suitable talents through appropriate channels, and effectively fill the gaps and deficiencies of the current company's talent team. 


\subsection{The Goal of World-class Enterprise Puts Forward a New Goal for the Construction of Human Resources Team}

The 19th National Congress of the Communist Party of China proposed to cultivate world-class enterprises with global competitiveness. The so-called world-class Chinese enterprises, state-owned power companies need to meet at least the following three standards. First, it has entered the leading ranks in terms of innovation drive, has become a leader in the allocation of state-owned resources, and has become a leader in promoting the global technological development of the industry. It also has an important voice in the industry's own promotion process. The second is to be able to enter the forefront of high-quality development, increase attention to indicators such as return on net assets, profit margins, $\mathrm{R}$ \& D investment, and added value, and be in a leading position in terms of revenue scale, quality, and efficiency. The third is to be able to enter the forefront in implementing the new development concept and become a model enterprise for fulfilling this development concept of mutual consultation, joint construction and sharing. It is also necessary to become a model enterprise that abides by the law and must be compliant and trustworthy in doing everything.[4]

Such world-class enterprise standards place extremely high requirements on the improvement of the comprehensive strength of state-owned power companies. The company needs to have a team of highly qualified personnel with strong action and execution that can help the company achieve the above goals as soon as possible. The company should further enhance the overall capabilities of the workforce, so that it has the qualities to match the world-class enterprises.

Therefore, state-owned power companies need to compare the needs of human resource teams that match the development goals of world-class enterprises, while clarifying the current overall situation of human resource teams. Identify the current gap between the company's human resources team and its goals, and then propose directions and measures to improve the construction of the human resources team.

\section{THE INFLUENCE OF POWER SYSTEM REFORM ON THE HUMAN RESOURCES TEAM OF STATE-OWNED POWER ENTERPRISES}

Along with the successive issuance of the "Circular 9" and supporting documents in 2015, the new electricity reform officially kicked off. Establish and improve a market system for the power industry that "has laws to follow, separate government from enterprises, regulate subjects, fair transactions, reasonable prices, and effective supervision", and strive to reduce electricity costs and rationalize price formation mechanisms, gradually break the monopoly, liberalize competitive business in an orderly manner, realize supply diversification, adjust industrial structure, improve technological level, control total energy consumption, improve energy utilization efficiency, improve safety and reliability, promoting fair competition, energy conservation and environmental protection has become the main goal of the new round of power system reform.

\subsection{Profit Margin Brought About by Reform of Transmission and Distribution Prices}

Before the transmission and distribution price reform, the company's revenue mainly came from the difference between electricity sales and electricity prices. After the implementation of the power transmission and distribution price reform, the power transmission and distribution price is changed to be approved by the government according to the principle of "permissible cost plus reasonable income". This will be lower than the purchase price difference before the transmission and distribution price reform. In addition, in the newly revised "Provincial Power Grid Transmission and Distribution Price Pricing Method" in January 2020, the new investment is controlled by setting efficiency indicators, improving the allowable yield index, strictly identifying effective assets that can be accrued income, and reducing working capital, which further strengthen the cost constraints of the company. It also clearly stipulates that the total cost of materials, repairs, and labor should be approved at a rate no higher than $2 \%$ of the original value of the new fixed assets for transmission and distribution during the supervision cycle.

This requires the company to further improve efficiency and reduce costs in various ways to ensure that the company's profit space is not lost. As an important part of the company's operating costs, labor costs account for a relatively high proportion, and compared with other permitted costs such as depreciation, materials, and repair costs, labor costs have the largest room for adjustment, so by reducing labor costs The overall cost effectiveness of the company in achieving the pressure drop is most obvious. Reducing total wages is the most direct way to reduce labor costs. On the one hand, the overall salary expenditure can be controlled by appropriate salary reduction, and more importantly, the overall size of the workforce should be reduced by optimizing the workforce structure and improving labor efficiency. This requires the company to eliminate part of the personnel by carrying out the inventory of the talent team, and integrate and optimize the staff team, so as to achieve the purpose of reducing labor costs.[5] 


\subsection{The New Supervision Model Puts Forward New Demands on the Competence of Human Resources Team}

According to the "Circular 9" of the new electricity reform, the key points and paths of the new round of electricity reform are: in accordance with the system structure that controls the middle and releases both ends, orderly liberalizes the price of competitive links other than transmission and distribution, orderly opens electricity distribution business to social capital, and orderly releases power generation plans other than public welfare and regulation, and promote relatively independent trading institutions and standardize operations. This means that market access will be implemented on the power generation side and the power sales side, competition will be introduced, user choices will be liberalized, and a market structure of buying more and selling more will be formed. Prices will be formed by the market and the decisive role of the market in allocating resources will be exerted.

With the gradual deepening of the new electricity reform, electricity sales companies around the country have sprung up. The original monopoly of the stateowned power enterprises in the field of electricity sales was broken, and the business model that originally relied solely on electricity sales for profits was greatly affected. The company needs to further expand the company's service areas, develop new market-oriented business, and find new profit growth points for the company. The diversified development of the business of state-owned power enterprises has put forward new requirements for the ability and quality of employees. The existing talent team of relevant enterprises is mainly technical and technical personnel related to power grid operation and maintenance, and there is a lack of professional personnel who are closely related to market-oriented business such as marketing, marketing, and Internet.

\section{CONCLUSION}

The in-depth advancement of the reform of stateowned assets and state-owned enterprises and the reform of the power system has brought great challenges to stateowned power companies, while also presenting great challenges. The construction of human resource teams in state-owned power enterprises is facing new goals and requirements. New requirements are put forward for the overall quality, management mechanism, introduction and withdrawal methods of the human resources team. State-owned power enterprises should make timely adjustments to the management mechanism of human resources work and the direction of personnel training based on the actual situation of their own human resources and the changes in external situations. Actively respond to the impact of the reform on the company's human resources work, and continuously improve the efficiency and effectiveness of human resource management.

\section{ACKNOWLEDGMENTS}

This project is supported by the State Grid Corporation of China Technology Project "Research on Talent Supply and Demand Analysis Model and Supply Strategy Research Adapting to Company Strategy" (SGSC0000KXJS2000095).

\section{REFERENCES}

[1] Yuan, B., Reconstruction of State-owned Investor Model under State-owned Enterprise Classification Reform, in: Business Economics and Management, vol.3, Beijing, China, 2020, pp.75-85. DOI: 10.14134/j.cnki.cn33-1336/f.2020.03.007

[2] Song, D., Li, S., Mixed Ownership Reform and State-owned Enterprise Innovation Research, in: Qiushi Academic Journal, vol.47(1), Beijing, China, 2020, pp. 51-61, DOI: 10.19667/j.cnki.cn231070/c.2020.01.008

[3] Wang, W., An Analysis of the Key Links of Deepening the Reform of State-owned Assets and State-owned Enterprises in the New Era, in: National Circulation Economy, vol.33, 2019, pp. 7172, $\quad$ DOI: $\quad 10.16834 /$ j.cnki.issn10095292.2019.33.031

[4] Li, Q., Strategies for Selling Electricity Under the Situation of Power System Reform, in: Electrotechnical, vol.6, 2020, pp.313-134, DOI: 10.19768/j.cnki.dgjs.2020.06.053

[5] Yang, G., Yang, D., Yang C., Analysis on the Effect and Problems of Power System Reform, in: Integrated Circuit Applications, vol.37(01), 2020, pp. 106-107, DOI: 10.19339/j.issn.16742583.2020.01.047 